\title{
PECULIARITIES OF TRAINING FUTURE FOOD INDUSTRY ENGINEERS FOR CREATIVE VOCATIONAL ACTIVITIES
}

\section{O. Kurilo}

У статті теоретично обгрунтовано особливості підготовки майбутніх інженерів-педагогів харчової галузі до творчої професійної діяльності та визначено шляхи вдосконалення иієї підготовки. Сучасними вимогами до інженерів-педагогів харчової галузі в області промисловості та освіти є сформованість готовності до творчої професійної діяльності, яка включає спроможність означених фахівців забезпечити зростаючі потреби споживача та виробництва; наявність належного рівня знань із дисциплін професійної та практичної підготовки, володіння професійно-практичними навичками, щуо в свою чергу стане вагомим підгрунтям для професійного вирішення конкретних виробничих ситуащій, які повсякденно виникають на підприємствах харчової індустрії та освітньому прочесі.

Виявлено потенційні можливості освітніх програм спецііальності 015 Професійна освіта (Харчові технологіï) щэодо забезпечення формування готовності майбутніх інженерів-педагогів харчової галузі освітнього ступеня бакалавр до творчої професійної діяльності.

Визначено иляхи вдосконалення підготовки майбутніх інженерів-педагогів до творчої професійної діяльності. Зокрема, зорієнтованістю підготовки на оптимальну реалізацію творчого потенціалу майбутніх фахівців та створенням відповідних організаційно-педагогічних умов (активізація у здобувачів вищої освіти спонукальних мотивів до творчого самовираження у майбутній професійній діяльності; використання дидактичних можливостей дисциплін циклу професійної та практичної підготовки у досягненні очікуваних результатів творчого характеру; організація психолого-педагогічного супроводу здобувачів вищзої освіти щзодо формування складників готовності до творчої професійної діяльності).

Запропоноване дослідження дозволяє вирімувати питання проблем кадрів трудової міграџї̈ на рівні забезпечення якісної професійної освіти і навчання, зокрема у контексті посилення кадрового потенціалу харчової галузі щзодо їхньої готовності швидко орієнтуватися у змінних умовах праці в області промисловості та освіти

Ключові слова: інженер-педагог, професійна підготовка, професійна освіта, творча професійна діяльність, харчова галузь

Copyright (C) 2020, O. Kurilo. This is an open access article under the CC BY license (http://creativecommons.org/licenses/by/4.0).

\section{Introduction}

Entry of Ukraine in the World trade organization and negotiations about joining the Association with the European Union may be considered as an essential achievement of the development of economy of our country [1]. It opens new ways of market relations with other countries of the world, namely integration to the international world economy, creation of legal principles for conducting a stable predicted business and international trade; creation of the favorable climate for foreign investments; appearance of new supplying sources of raw materials; increase of the output volume of goods for both internal and external markets; increase of the goods circulation use of the world labor distribution [2]. It is indicated, especially by the total volume of financial and credit support from EU (1.5 bil euro), total volume of international technical help (385.7 bil euro); increase of the goods circulation from EU $(41.3 \%$ of the total volume of external trade of goods); growth of the number of Ukrainian companies, realizing export of goods to EU state-members (14545 for 2019); elaboration and implementation of legislative documents for supporting small business (Law of Ukraine "On introducing changes to several legislative acts of Ukraine about decreasing a pressure on business from market control bodies"); improvement of the system of monitoring and controling the state help for enterprises and elaboration of criteria for estimating the state help in different branches of economy; support of the farm economies development (budgetary expenditures as 1 bil hrn for 5010 farmers and agricultural service cooperatives) and so on [3]. These processes directly influence the food branch of our country, which development depends not only on elaboration and implementation of effective production technologies, but also on the effective use of human resources.

The insufficient introduction of world innovations in the sphere of formation and use of human resources in material production is accompanied by the loss of competitiveness by them not only at the international level, but also at the state and local ones. Today there are needed specialists, able to move Ukraine at positions of the developed world countries in short terms. This important task can be successfully realized at training highly competent, vocationally competitive specialists, able to think scientifically and orient in own practical activity, to make correct decisions in one or another production situation, 
by higher educational institutions. So, there is a necessity to strengthen the staff potential of the food industry as to its readiness to orient fast in changeable labor conditions in the field of industry and education.

\section{Literary review}

A necessity to raise the level of vocational training of specialists for different branches of industry is stressed in such normative-legal documents as [4] comprehensive development of a human as a person and the highest value of the society, his/her talents, intellectual, creative abilities, formation of values and competences, necessary for successful self-realization, [5] training of the competitive human capital for the highquality and innovative development of the country, selfrealization of a person, provision of needs of the society, labor market and state in high-quality specialists, [6] coordination of the education structure with needs of the modern economy and integration of Ukraine into the European economic and cultural space, guaranteeing of the correspondence of the education content to needs and challenges of the modern society, creation of conditions for the continuous renewal of the education content, transformation of education is the mover of the knowledge economy, [7] - satisfaction of needs of a person, society and state in educational services in the sphere of vocational education and learning, taking into account formation tendencies of the native labor market and world experience; guaranteeing of the equal access to the high-quality vocational education and learning throughout life that favors the socio-economic growth of the country and its safety, order of MES of Ukraine [8] improvement of the system of pedagogical education for creating a base for training pedagogical workers of the new generation, Order of the president of Ukraine [9] increase of availability of high-quality competitive education according to requirements of the innovative sustainable development of the society, economy, guaranteeing the personal development of a human, according to his/her individual abilities, needs, based on lifelong learning, Order of the president of Ukraine [10] - implementation or European life standards in Ukraine, and its entry on leading positions in the world and so on.

The scientific-theoretical base for determining content principles of the research is philosophicalmethodological, general scientific, pedagogical and psychological principles and positions: in the sphere of higher education, especially pedagogical mastership and creativity $[11,12]$ - an importance of the academician's creative work is a Conception of pedagogical mastership and offered ways for its realization, which main peculiarity was considered by the scientist as a diligent selection (by testing and interview) and individual work with young people with an inclination to pedagogy, on whose training new directions of psychological-pedagogical studies and pedagogical technologies, created by him, were oriented, that is also a prognostic character of his scientific contribution, $[13,14]$ - study of pedagogical creativity that occupies a special place among different types of creativity, because just it determines vectors of the dynamic development of all creative processes of mankind; in the sphere of vocational engineerpedagogical education, in particular main aspects of the vocational-pedagogical training of an engineer-educator $[15],[16,17]$ - designing of the system of pedagogical training of future engineers-educators using a new means system integration of the activity, personally oriented and competence approaches, problem of the personal structure and activity of an engineer-educator are reveled in studies [18]; in the sphere of psychology: the study of general creative abilities that success in many types of activity depends on, creativity conception, where creativity is a general characteristic of a personality and influences creative productivity, not depending on a sphere of creative activity manifestation - $[19,20]$.

Searches of ways for the effective prognostication and development of the food industry of Ukraine are realized by native scientists [21] and [22]. At the same time peculiarities of the training of future engineers-educators of the food industry for the creative vocational activity are left beyond attention

In general, researchers, not depending on research object and subject, give a special importance just to the human potential, which development is connected with overcoming of crisis phenomena in the society, especially in the sphere of industry and education. A human is a part of wealth and aim of social production, being considered not only as a factor of social development, but also as a main subject, using its results.

Social welfare was connected with the development of human resources: «Wealth production is not only a way for supporting the human life, satisfying his/her needs and developing forces - physical, intellectual and moral. But a human him/herself, the main means of producing this wealth, is a final aim of wealth» [23]. An essential role was given to a human and his/her potential possibilities in production modernization, understanding a human capital as a totality of knowledge, competences and qualifications that play leading roles in the increase of production effectiveness [24].

Two interconnected interpretations of human resources in works $[25,26]$ may be considered substantiated:

- As widening of choice;

- As the improvement of possibilities and abilities of a human, depending on how effective a human uses economic, social, political and other preconditions for own interests, on availability of necessary resources, right to dispose of them. In other words, the human development in the growth of human possibilities - all, can be done and achieved by humans at a certain degree of life choice freedom.

Work [27] considers the human potential as a process of creative self-realization, saving its natural essence, and is interpreted as a personal responsibility for own destiny, ability to save natural bases of own individuality.

The importance of the further development of the human potential of the food industry of Ukraine is connected by us with implementation of new types of enterprises, modern technologies of food products and educational requirements to the vocational training of specialists, especially, engineers-educators in the food branch.

\section{Research aim and tasks}

The aim of the research is to ground theoretically training peculiarities of future engineers-educators in the 
food branch to the vocational activity and to determine ways of its improvement.

The following tasks were set for attaining the research aim:

1. To analyze requirements to engineers-educators in the food branch in the field of industry and education;

2. To reveal potential possibilities of educational programs of specialty 015 Vocational education (Food technologies) as to providing the formation of the readiness of future engineers-educators in the food branch of the bachelor educational degree to the creative vocational activity;

3. To determine ways of improving the training of future engineers-educators in the food branch to the creative vocational activity.

\section{Materials and methods}

Under modern conditions, when new technologies dominate in production and the effectiveness of socioeconomic transformations mainly depends on the intensity of innovative processes of most diverse spheres of vocational activity, a need in specialists with the brightly expressed creative-personal potential, improvement of their vocational training and search for non-standard ways of pedagogical conditions realization for improving the vocational quality of future engineers-educators of the food branch is urgent as never before. It is important that as a result of the increased speed of changes, taking place in the sphere of food technologies, future engineers-educators of the food branch must cope successfully with such tasks as a change of a sphere of vocational activity during a career, adaptation to new conditions of the vocational activity, continuous knowledge renovation.

It becomes understood for the whole educational community, connected with the training of future specialists of the food branch, especially, engineers-educators, that it is possible to train a competitive specialist only under conditions of the effective cooperation between educational institutions and food enterprises. And it becomes possible only is a higher educational institution understands needs of the modern production and is able to train a young specialist to the further vocational career, and enterprises, in their turn, are ready to work with a graduate. An educational institution faces a complicated task to educate a mobile, vocationally and socially adapted specialist of the food branch, able to work at different posts at different forms of labor organization and production under conditions of competition [28].

The following types of qualification are offered for the branch of vocational education according to the educational degree of specialty 015 «Vocational education (by specializations)»: young specialist - «expert of production training»; bachelor - «teacher of practical training in the branch (power industry, machinery construction and so on)»; master-educator - teacher of special training disciplines in the branch (power industry, machinery construction and so on)»; master-scientist «engineer-educator - researcher (economist-educatorresearcher and so on)»; master-manager - «engineereducator - manager (economist-educator - manager and so on)» [29]. Alongside with qualifications, connected with the pedagogical activity, applicants of higher educa- tion get a qualification of specialists in the field of food technologies.

These qualifications belong to the complex group of professions that function at the same time in two heterogenous systems - «person - person», «person - technique» and their modifications. Alongside with the readiness to the vocational activity, such specialists must have special knowledge, to realize the learningproducing, organizational-methodical activity for the vocational training of students in the system of vocational-technical education and also qualified workers at enterprises.

The vocational activity of an engineer-educator of a correspondent branch is a complex phenomenon by its structure and directionality, and differs from the activity of specialists of other professions, because components of technical and pedagogical work are integrated it its structure. Engineering-pedagogical education is the process of mastering systematized knowledge, abilities and skills of the engineering-technical, production-technological and methodical character, in which result, based on purposefully formed vocationally important qualities, a person gains an objective possibility and documented right for training qualified specialists of different educational degrees [30].

So the content of training of future engineerseducators of the food branch must take into account modern needs of industry and education, such as: new technologies of the food branch, not depending on the production specificity; involved resources of world producers; modernization of the food industry; change of the type and content of labor of specialists in the food production branch; qualitative and quantitative transformation of labor resources in the industry; change of interrelations between employers and employees; taking into account of main criteria of survival and presence of highquality, economically effective and ecologically safe products, corresponding to increased requirements of consumers and actual high ones of quality standards ISO 9000-9004 at the realization market; requirements to vocational workers, main of which are the deep theoretical preparation, communicability, ability to fast reaction, ability to prospective thinking, system of organization, labor discipline; ability of young specialists to the practical activity; integration between the vocational activity and production; mastering of the vocational knowledge as a way of self-identification and self-consciousness of a workers as a means of developing not only a learning person, but also production.

The vocational activity of future engineerseducators of the food branch is characterized by the presence of necessary competences, which successful combination provides the high effectiveness and productivity of their activity under conditions of competitiveness of market relations.

For achieving the correspondence of training results of higher education applicants in specialty $015 \mathrm{Vo}-$ cational education (Food technologies) to the national frame of qualifications, based on European and national standards and principles of education quality guaranteeing, taken into account labor market requirements to workers' competences and implemented for harmonizing legislative norms in the spheres of education and socio- 
labor relations, set the effective interaction between the sphere of education and labor market [31], we find it necessary to favor the formation and realization of the creative potential of future engineers-educators of the food branch, able to react fast to changes in the food industry and vocational education.

It is necessary to stress that under conditions of the extremely dynamic market, the cooperation between educators and employers at creating and realizing educational programs gained a special importance. The aim of the training is a competence model of a specialist (profile), created at the active participation of teachers, employers, graduates, vocational organizations and so on.

Today there is a conventional division of competences in two groups: subject-special competences and general ones. According to the definition, first ones depend on a subject branch, they just determine the profile of an educational program and qualification of a graduate, they make each educational program individual. But there are other ones, no less important competences, mastered by a higher education applicant at realizing an educational program, but they are universal, not connected to a subject branch. This is, for example, the ability to learning, creativity, mastering of base information technologies and so on [32].

From our point of view, it is important to study general competences, realized within the Tuning project. Results and recommendations, obtained in it as a list of most important general competences, are widely used in the world for creating educational programs. General competences are classified by the three categories instrumental (cognitive, methodological, linguistic and technological abilities); interpersonal (communication skills, social interaction and cooperation); system (combination of understanding, receptivity and knowledge, ability to plan changes for improving systems, elaborating new ones). These categories cover 30 competences [33].

So, the training of future engineers-educators to the vocational activity will be based on tendencies of food industry development, perspectives of vocational education and potential possibilities of higher education applicants.

\section{Research results and their discussion}

For revealing potential possibilities of educational programs of specialty 015 Vocational education (Food technologies) as to providing the formation of the readiness of future engineers-educators of the food branch of the bachelor educational degree to the creative vocational activity, we have analyzed program competences of profiles of the Ukrainian engineering-pedagogical academy (HEI 1), Uman state pedagogical university, named after Pavlo Tichyna (HEI 2), and Chernihiv national pedagogical university, named after T.G. Shevchenko (HEI 3).

First of all, we selected vocationally important competences for creative vocational activity realization, based on the Tuning project classification:

\section{General competences:}

- Instrumental (ability to analysis and synthesis; ability to organize and plan; skills of dealing with information; ability to solve problems; ability to make decisions);
- Interpersonal (ability to work in a team; interpersonal skills);

- System competences (research skills ability to adapt to new situations; ability to generate new ideas; ability to leadership; ability to work autonomously; ability to elaborate projects and to manage them; ability to initiative and entrepreneurship; striving for success).

Special competences:

- Mastering of a subject field at higher level that is mastering new methods and technique (of research), knowledge about new theories and their interpretations;

- Critical tracing and understanding of the theory and practice development;

- Operating by methods of independent research and ability to explain its results at higher scientific level;

- Ability to make an original contribution in a discipline according to canons of a certain subject field;

- Demonstration of originality and creative approach; level.

- Mastering of competences at the professional

The analysis of the correspondence of the aforesaid competences to profiles of educational programs for training future engineers-educators of the food branch gives grounds to state that program competences don't fully provide the formation of the readiness to the creative vocational activity. It concerns especially general competences - ability to organize and plan own activity (HEI 2); ability to solve problems (HEI 2); ability to make decisions (HEI 2); ability to work in a team (HEI 2); research abilities (HEI 1-2); abilities to adapt to new situations (HEI 2-3); ability to generate new ideas (HEI 1); ability to leadership (HEI 1-3); ability to work autonomously (HEI 1-3); ability to elaborate projects and to manage them (HEI 3); ability to initiative and entrepreneurship (HEI 2-3); striving for success (HEI 1-3); special competences - operation by methods of independent research and ability to explain its results at the higher scientific level (HEI 3); ability to make an original contribution in a discipline according to canons of a certain subject field (HEI 3).

At the same time there is observed a certain imbalance of the influence on final results of the training of future engineers-educators as to providing the formation of the readiness to the creative vocational activity, thus, for example, the ability to analysis and synthesis is provided as follows: Ability to abstract thinking, analysis and synthesis of new ideas at actions in non-standard situations (HEI 1); ability to analyze socio-political relations and formation of an adequate model of social behavior, ability to analyze results of calculations, measurements and observations in a subject field (HEI 2); ability to orient in historical processes, events, facts, to use acquired knowledge for prognosticating social processes, to analyze and to assess phenomena of the political development; ability to analyze and to assess socioeconomic processes at the mega-, macro-, meso- and microeconoomic levels; ability to understand and to analyze relationship between the society and external environment and to use main nature laws in the vocational activity (HEI 3). Another example, interpersonal skills: ability to work in a team, using skills of interpersonal cooperation (HEI 1); ability to self-presentation under 
different conditions of the general and vocational activity (HEI 2); ability to form a worldview, understanding of the society development principles HEI (3) and so on.

Taking into account the content or even absence of competences, providing the formation of the readiness to the vocational activity, there is a necessity to improve the influence on a personality of future engineerseducators of the food branch.

Strengthening of the staff potential of the food industry as to its readiness to orient fast in changeable labor conditions in the field of industry and education is provided, especially, by training future engineerseducators of the food branch for the vocational creative activity, namely: training orientation on the optimal realization of the creative potential of future specialists and creation of correspondent organization-pedagogical conditions (activation of motivations to creative selfexpression in the future vocational activity of higher education applicants; use of didactic possibilities of disciplines of a cycle of the vocational and practical training in achieving expected creative results; organization of the psychological-pedagogical support for higher education applicants as to the formation of components of the readiness to the creative vocational activity).

We think, that the elaborated training model for future engineers-educators of the food branch will be effective if:

- The optima realization of the creative potential of higher education applicants is an expected result of the educational process, based on the idea of studentcentrism at observing the dynamic strategy of the vocational education and realizing the system, competence, acmeological, resource and creative approaches;;

- There is the interconnection between the determined training components and the process of forming the readiness of higher education applicants to the creative vocational activity;

- To implement the mentioned organizationalpedagogical conditions at the level of educational process (algorithm of actions for achieving results of mastering theoretical knowledge, practically oriented and independent creative activity, certain topic or a discipline as a whole), levels of a pedagogical situation (optimal concentration of the influence on the development of a creative personality of future engineers-educators);
- To provide the dynamic combination of all components of the readiness of higher education applicants to the creative vocational activity, based on general and special competences of the profile training of future engineers-educators of the food branch.

So, prospects of further studies will be in checking ways for improving training of future engineerseducators of the food branch for the creative vocational activity.

The training of future engineers-educators for the creative vocational activity allows to solve problems with the staff of labor migration at the level of providing the high-quality vocational education and learning, especially in the context of strengthening the staff potential of the food branch as to its readiness to orient fast in changeable conditions in the field of industry and education.

The model of a specialist of "new type" differs by deep vocational knowledge in integrated professions, economic and legal knowledge, ability to technical and social creativity, self-improvement, readiness to the work under competitive conditions at different organization forms of production and labor that favors solving problem of employment of higher education graduates.

\section{Conclusions}

1. The modern requirements to engineerseducators of the food branch are the formed readiness for the creative vocational activity, including the ability of these specialists to satisfy growing needs of a consumer and production; proper level of knowledge in disciplines of the vocational and practical training, mastering of vocational-practical skills that in its turn become an important ground for the vocational solution of concrete production situations, every day appearing at food industry enterprises and in the educational process.

2. Actual educational programs of specialty 015 Vocational education (Food technologies) of the bachelor educational degree partially satisfy the formation of the readiness of future engineers-educators of the food branch for the creative vocational activity.

3 . The improvement of the training of future engineers-educators as to their readiness to orient fast in changeable labor conditions in the field of industry and education is considered as the optimal realization of the creative potential of future specialists and creation of correspondent organizational-pedagogical conditions.

\section{References}

1. On the Ratification of the Protocol on the Accession of Ukraine to the World Trade Organization: Zakon Ukrainy No. 250VI. 10.04.2008. URL: https://zakon.rada.gov.ua/laws/show/250-17 (Last accessed: 15.12.2019)

2. Lazarieva T. A. Teoretychni i metodychni zasady pidhotovky maibutnikh inzheneriv-tekhnolohiv kharchovoi haluzi do tvorchoi profesiinoi diialnosti: doctors these. Kharkiv: Ukrainska inzhenerno-pedahohichna akademiia, 2014. $625 \mathrm{p}$.

3. Zvit pro vykonannia uhody pro asotsiatsiiu mizh Ukrainoiu ta Yevropeiskym soiuzom (za 2019 rik). URL: http://euua.org/sites/default/files/inline/files/zvit_implementation-2019-4.pdf (Last accessed: 15.03.2020)

4. Pro osvitu: Zakon Ukrainy Nö. 2145-VIII. 05.09.2001. URL: https://zakon.rada.gov.ua/laws/show/2145-19 (Last accessed:

5. On Higher Education: Zakon Ukrainy No. 1556-VII. 01.07.2014. URL: https://zakon.rada.gov.ua/laws/show/1556-18 (Last accessed: 14.03 .2020$)$

6. Kontseptsiia rozvytku osvity Ukrainy na period 2015-2025 rokiv: proekt. SDH «Osvita», 2014. URL: http://educationua.org/ru/draft-regulations/319-proekt-kontseptsiya-rozvitku-osviti-ukrajini-na-period-2015-2025-rokiv (Last accessed: 14.03.2020)

7. Kontseptsiia rozvytku profesiinoi osvity i navchannia v Ukraini (2010-2020 rr.). URL: http://tnkk.at.ua/proekt2010_2020.doc (Last accessed: 14.03.2020)

8. Pro kontseptsiiu rozvytku pedahohichnoi osvity: nakaz Ministerstva osvity i nauky Ukrainy No. 776. 16.07.2018. URL: https://mon.gov.ua/ua/npa/pro-zatverdzhennya-koncepciyi-rozvitku-pedagogichnoyi-osviti (Last accessed: 14.03.2020) 
9. Pro natsionalnu stratehiiu rozvytku osvity v Ukraini na period do 2021 roku: Ukaz Prezydenta Ukrainy No. $344 / 2013$. 25.06.2013. URL: https://zakon.rada.gov.ua/laws/show/344/2013 (Last accessed: 14.03.2020)

10. Pro stratehiiu staloho rozvytku «Ukraina - 2020»: Ukaz Prezydenta Ukrainy No. 5/2015. 12.01.2015. URL: https://zakon.rada.gov.ua/laws/show/5/2015 (Last accessed: 14.03.2020)

11. Ziaziun I. A. Filosofski zasady osvity: osvitni i vykhovni paradyhmy, osvitni tekhnolohii, dialektyka pedahohichnoi dii / ed. by Nychkalo N. H., Ziaziun I. A., Leshchenko M. P., Soldatenko M. M. et. al. // Pedahohichna maisternist u zakladakh profesiinoi osvity: monograph. Kyiv: In-t pedahohiky ta psykholohii prof. osvity APN Ukrainy, 2003. P. 246.

12. Pedahohichna maisternist: textbook / ed. by Ziaziun I. A. Kyiv: SPF Bohdanova A. M., 2008. 376 p.

13. Pedahohichna tvorchist: metodolohiia, teoriia, tekhnolohii: monograph / Andrushchenko V. P., Sysoieva S. O., Huzii N. V. et. al; ed. by Sysoieva S. O., Huzii N. V. Kyiv: NPU im. M. P. Drahomanova, 2005. 183 p.

14. Sysoieva S. O. Osnovy pedahohichnoi tvorchosti: textbook. Kyiv: Milenium, 2006. 344 p.

15. Auer M. E., Dobrovska D., Edwards A. New pedagogic challenges in engineering education and the answer of IGIP// 2011 Frontiers in Education Conference (FIE). 2011. doi: http://doi.org/10.1109/fie.2011.6142845

16. Briukhanova N. O. Teoriia i metodyka proektuvannia systemy pedahohichnoi pidhotovky maibutnikh inzhenerivpedahohiv: Abstract doctors theses. Luhansk, 2011. 42 p.

17. Bryukhanova N. O. System Integration of Activity-Based, Personality-Oriented, and Competence Approaches as a Design of Planning of System for Future Teacher-Engineers' Pedagogical Training // Problemy inzhenerno-pedahohichnoi osvity. 2013. Issue 38-39. P. 36-43. URL: http://nbuv.gov.ua/UJRN/Pipo_2013_38-39_7 (Last accessed: 10.01.2020)

18. Nychkalo N. H. Rozvytok profesiinoi osvity v umovakh hlobalizatsiinykh ta intehratsiinykh protsesiv: monograph. Kyiv: Vyd-vo NPU imeni M.P. Drahomanova, 2014. 125 p.

19. Guilford J. P. Creative talents: Their nature, uses and development. Buffalo, New York: Bearly Limited, 1986. 139 p.

20. Torrance E. P. The Nature of Creativity as Manifest in its Testing. The Nature of Creativity / ed. by Sternberg R. J. Cambridge: Cambridge Univ. Press, 1988. P. 32-75.

21. Borshchevskyi P., Sychevskyi M., Troian V. Kharchova promyslovist Ukrainy: suchasni tendentsii ta perspektyvy rozvytku // Ekonomika Ukrainy. 2003. Issue 8. P. 45-49.

22. Sychevskyi M. P. Orhanizatsiino-ekonomichnyi mekhanizm rozvytku kharchovoi promyslovosti Ukrainy (teoriia, metodolohiia, praktyka): doctors theses /. Kyiv, 2005. 468 p.

23. Marshall A. Principles of economics. London, 1983. P. 246. doi: http://doi.org/10.1007/978-1-349-15213-1

24. Schultz, T. W. Reflections on Agricultural Production, Output and Supply // Journal of Farm Economics. 1956. Vol. 38, Issue 3. P. 748-762. doi: http://doi.org/10.2307/1234459

25. Sen A. Razvitie kak svoboda. URL: http://library.khpg.org/index.php?id=1436785369 (Last accessed: 13.03.2020).

26. Sen A. Ob etike i ekonomik / ed. by Aleskerova F.G., Shzubina A. N. Moscow: Nauka, 1996.160 p. URL: https://dahluniversitymanagementinstitute.files.wordpress.com/2017/10/shen.pdf (Last accessed: 13.03.2020)

27. Volkova N. V. Conditions of professional training of future engineers-teachers in the field of food technologies in the context of modern European integration processes // Suchasni informatsiini tekhnolohii ta innovatsiini metodyky navchannia $\mathrm{V}$ pidhotovtsi fakhivtsiv: metodolohiia, teoriia, dosvid, problemy. 2016. Issue 46. P. 137-140.

28. Doluda A. V. Contradictions Training of Future Engineer of Food Industry in Teaching Design Food Enterprises // Problemy inzhenerno-pedahohichnoi osvity. 2013. Issue 38-39. P. 219-225.

29. Kovalenko O. E., Briukhanova N. O., Melnychenko O. O. Teoretychni zasady profesiinoi pedahohichnoi pidhotovky maibutnikh inzheneriv-pedahohiv v konteksti pryiednannia Ukrainy do Bolonskoho protsesu: monograph. Kharkiv: UIPA, 2007. 162 p.

30. Hura S. O. Orhanizatsiino-pedahohichni umovy adaptatsii maibutnikh inzheneriv-pedahohiv: Abstract PhD theses. Kharkiv, 2004. 20 p.

31. Pro vnesennia zmin u dodatok do postanovy Kabinetu Ministriv Ukrainy vid 23.11.2011 r. No. 1341 «Pro zatverdzhennia Natsionalnoi ramky kvalifikatsii»: postanova Kabinetu Ministriv Ukrainy No. 509. 12.06.2019. URL: https://zakon.rada.gov.ua/laws/show/1341-2011- \%D0 \%BF (Last accessed: 15.01.2020)

32. Rozroblennia osvitnikh prohram: handbook / Zakharchenko V. M. et. al.; ed. by Kremenia V. H. Kyiv: DP «NVTs «Priorytety», 2014. $120 \mathrm{p}$.

33. Dyman T. M., Bonkovskyi O. A., Vovkohon A. H. Yevropeiskyi prostir vyshchoi osvity ta Bolonskyi protses: handbook. Odesa: NU «OMA», 2017. 106 p.

Received date 10.12.2020

Accepted date 12.02.2020

Published date 31.03.2020

Olga Kurilo, Postgraduate Student, Department of Vocational Education, Labor Training and Technology, Berdiansk State Pedagogical Univarsity, Schmidta str., 4, Berdiansk, Zaporizhzhia region, Ukraine, 71100

E-mail: olgakurilo_1990@ukr.net 